\title{
GOVERNMENT CONTROL OF OIL AND GAS PIPE LINES IN ALBERTA
}

\author{
MARTIN M. OLISA*
}

\section{INTRODUCTION}

This paper deals with the Alberta Government policy on, and control of, oil and gas pipe lines within the jurisdiction of the Provincial Government, in relation to public interest. The controversial constitutional question of whether the Provincial Legislature or Parliament of Canada has jurisdiction over gathering systems which cross inter-provincial boundaries, is not discussed. For the present purpose, it is assumed that the Provincial Government has jurisdiction and so, "pipe line" includes all pipe lines in the province except those caught by section 3 (b) of the Pipe Line Act $1958,{ }^{1}$ that is:

a pipe line for which there is in force

(i) a certificate, or

(ii) an order exempting the pipe line from a certificate, issued or made by the National Energy Board under the National Energy Board Act (Canada).

It is proposed to state and discuss the present government policy, to consider the laws and regulations in order to ascertain whether or not, in public interest, they are effective in solving the rather dissimilar problems raised by oil and gas pipe lines in Alberta. Alternative policy will also be considered.

\section{THE PRESENT POLICY}

In outlining the position and policy to which the Provincial Government has consistently adhered on oil and gas, the Premier, Hon. E. C. Manning, said: ${ }^{1 a}$

We take the position that our first responsibility is to encourage under a system of private enterprise the orderly and efficient development of our oil and gas resources under sound engineering and conservation practices.

In the disposition of gas, our policy has been and will continue to be to encourage adequate supply to meet the present and future requirements of Alberta before we approve export to markets outside the province.

Enquiry shows that this policy has not changed. The fate of the pipe line is tied to the fortunes of the oil and gas industry. Therefore, it is within the context of, and consistent with the above comprehensive policy statement on oil and gas and the administration of the Pipe Line Act 1958 , together with the regulations thereto, that a specific policy on pipe lines emerges. It is that of granting pipe line permits to as many applicants as qualify under the Act, leaving the forces of competition to determine the necessity and location of each pipe line.

In the grant of permits and licences and in the operation of pipe lines, measures have been adopted to put the policy into action. The appli-

- B.Sc., LL.B. (London), LL.M. (Alta.) of the 1967 graduating class.

1 S.A., 1958, c. 58.

1a The Royal Commission on Energy: Submission of Honourable E. C. Manning, Premier of Alberta Concerning Natural Gas (1958) at 1. 
cation of these measures culminates in the service of public interest. A complete list of public interests to be served is not possible but the following deserve special attention:

(a) Encouragement of adequate supplies to meet the present and future requirements of Alberta;

(b) Maintenance of incentive and orderly development;

(c) Practice of proper conservation;

(d) Providing that a fair and equitable price is paid for the oil and gas;

(e) Providing facility for adequate supply to the largest number of Alberta communities;

(f) Safeguarding the interest of owners, producers and consumers within the province;

(g) Providing that adequate revenue is derived from pipe line operation.

The pipe line undertaking is only one phase of the oil and gas industry and a policy consideration of it must, as it were, fit into the wider policy consideration of the oil industry which in turn, complements the national economic policy. The emphasis is on free economy and competitive enterprise as opposed to public enterprise and monopoly. Under the present system and following from the Premier's policy statement, the Government does not envisage the extension of public enterprise, nationalisation or the encouragement of monopoly in pipe line business.

The laws and regulations are the most authoritative guide in putting the policy into effect. By enacting the laws, the legislature is doing a necessary duty of shaping the economic system in which business is to function. The necessity of control lies in the fact that the behaviour of business is not a matter for business alone; investments, employment, dividends, salaries, price, quality, quantity of service and other incidents of pipe line undertaking affect the well-being of thousands of citizens. Thus public interest does demand a measure of control even of a free economy. The attitude of the regulatory authorities seems to be to limit public regulation to fields where it is unavoidable.

\section{THE LAWS AND REGULATIONS}

In considering the problems involved in the regulation of the transportation of oil and gas by pipe lines, a distinction must be drawn between 'oil' and 'gas' pipe lines. An oil pipe line is a carrier only and carries oil owned by others and delivers it to refineries. It is not a purchaser of oil.

Crude oil (a raw material) is purchased by refiners on short term contracts in order to maintain flexibility of supply against changing supply sources and changing demand.2

It does not deliver oil to the ultimate consumer and competes with other forms of transportation.

On the other hand, the gas pipe line operation is less flexible than that of oil pipe lines and does not face up to competition from rail, truck

2 Submission to the Royal Commisison on Energy: Imperial Oll Limited (1958), at 35. 
or ship. Gas can be stored in natural underground storage. The trunk gas pipe line is a monopoly or semi-monopoly which purchases, transmits and sells gas on long term contracts, and supplies gas to the ultimate user. It is not a common carrier. It possesses the facilities for the supply of, and does supply, gas in sufficient quantities where and when it is required. Wider problems also involved in pipe line operation such as monopoly, unfair competition and conservation will be considered later.

In a free economy, regulation and control is designed to guard the public interest especially if there is a clear danger to such interest. The Pipe Line Act 1958, ${ }^{2 a}$ has, by and large, served the purpose. The Act applies to pipe lines subject to provincial jurisdiction but the following are expected. ${ }^{3}$

A pipe line situated wholly within the property of a refinery or a prossessing, marketing, or manufacturing plant; that portion of a distribution system within the boundaries of a city, town or village; a pipe line system wholly within the property of a consumer and supplying oil or gas as fuel; and a gas installation within the meaning of the Gas Protection Act.

(a) Measures affecting the grant of permits and licences.

The regulations for a grant of permits and licences have a very important bearing on the policy and the problems of oil and gas pipe lines. Therefore, they merit close examination. In its submission to Royal Commission on Energy, the Conservation Board commented as follows: ${ }^{4}$

... for most purposes oil lines and gas lines are dealt with in the Act on the same basis. However, the Act provides for a closer examination of an application for a permit for the construction in the case of a gas line, and the consideration in such a case is the financial responsibility of the applicant, any public interest that may be affected by the outcome of the application, and the needs and general good of the residents of the Province as a whole.

The first step is that a formal application is made to the Department of Mines and Minerals for a permit to construct a pipe line. The information to accompany the application includes a plan showing the proposed route of the pipe line, location and capacity of each installation, together with specification sheet which shows additional information as required by the Department. Usually the Minister orders a publication in local newspapers of the proposed route. The Minister may refer the application for an oil pipe line to the Oil and Gas Conservation Board for advice. In the case of a gas pipe line, the application may be referred to the Gas Utilities Board for advice. The Minister may have regard to the advice of the Board in granting the permit and may grant the permit subject to certain conditions such as the dates of commencement and completion and alterations in the plan. If the application is approved, a construction permit is issued allowing construction of the line, provided however, that the right-of-way has been obtained from the landowners, either by agreement or by an order for Right-of-Entry made by the Public Utilities Board.

In considering the application referred to it,

it is the Board's practice to hold a hearing when applications may be in conflict, when there appear to be reasons why the applicant's plan may conflict

2a Ante, n. 1.

+ Submission to the Royal Commission on Energy: Oil and Gas Conservation Board (1958), at 68-69. 
with other persons or when it appears desirable to extend the opportunity to make representations concerning the project, as in a case of complexity or involving intangible factors. ${ }^{5}$

This suggests that duplication of pipe lines by competing applicants can be prevented but in practice it does not necessarily follow. The application may not be referred to the Board and even when it is, the Minister is not bound to accept its advice.

Prior to 5th April, 1962, i.e. under the former Act, the Board required the applicant to submit detailed engineering and technical information, methods of financing, evidence of the suitability and acceptibility of gas to the proposed market and data respecting the geology and reserves of the field, among other things. In addition to ensure that the project is economically and technicially sound, the Board had regard to public interest ${ }^{6}$ including the duplication of pipe lines. Under the present Act, the Board's examination and report are made from a technical point of view only. This relaxation of the requirements for a grant of permit indicates a slight change of attitude on the part of the Government. The change does not appear to be for the better; it has given rise to at least one unfortunate result which is also potentially disastrous. The result is destructive competition, discussed on page 232 .

(b) Measures relating to Conservation

In order to prevent waste, section 37 (b) of the Oil and Gas Conservation Act, 1957, ${ }^{\text {oa }}$ [S.A. 1957, c. 63] empowers the Conservation Board to:

... require that any gas be gathered, processed, if necessary and the gas or products therefrom marketed or injected into an underground reservoir for storage or for any other purpose.

The section concerns both producers and pipe line operators. Sections 32 and 32 (a) provide for action to be taken in the event of and occurence of a break in, and loss of oil from, a pipe line transmitting oil. Finally, there is a system of inspection of pressure plants which form the whole or any part of an installation of a pipe line for purposes of safety and conservation.

(c) Measures to ensure adequate supply of oil and gas

The primary object of the Gas Resources Preservation Act, 1956, ${ }^{16 \mathrm{~b}}$ is to guarantee the present and future gas supply for the residents of the Province. The Act provides that no gas shall be removed from the Province except under a permit granted by the Oil and Gas Conservation Board.? The permit is granted only with the approval of the Lieutenant Governor-in-Council.

In addition, since May 15, 1945, each Crown Oil and Gas lease includes the following covenant:

The lessee covenants, and it is express condition upon which this lease is granted, that natural gas produced from the location shall be used within the Province of Alberta, unless the consent of the Lieutenant Governor in Council to its use elsewhere has been previously obtained. Upon any breach if this covenant and

5 Ibid, at 69.

6 Ibid, at 70.

Ba S.A. 1957, c. 63.

ob S.A. 1956, c. 19 .

7 Section 5 provides for application for permit to remove gas, section 7 for hearing, and section 23 for penalty. 
condition occurring whether with or without the consent or knowledge of the lessee, this lease shall forthwith be terminated, shall become null and void, and shall cease to have any further force or effect, and the rights granted by the lease, freed and dischargd from any interest or claim of the lessee or any other person or persons whomsnever claimed by, through or under the lessee, thereupon shall revert to Her Majesty.

Other regulatory measures are found in sections 42,43 and 46 of the Oil and Gas Conservation Act. Section 42 empowers the Board, with the approval of the Lieutenant Governor-in-Council to declare a proprietor of a pipe line to be a common carrier. Under section 43, the Board, with a similar approval, may declare a person who purchases, produces or otherwise acquires oil or gas in a pool to be a common purchaser of oil or gas from the pool or pools designated by the Board. Section 46 provides that the Board may, after hearing, order the owner or operator of a well gas pipe line or processing plant to process, gather, deliver, buy or sell gas and construct the necessary facilities. There is a right of appeal to the Appellate Division on an order made under this section. The Board of Public Utilities Commissioners, on the application of any person interested, may determine the price or charges for gas upon a purchase or sale if no agreement is reached on an order made under section 46.

A declaration under section 42 imposes additional obligation on the pipe line company because the company is brought within the competence of the Board to exercise its regulatory control over such matters as tolls or tariff of such a company. However,

At present the Board is not acting under its powers to designate carriers and purchasers, but acts under its power of regulating production in issuing monthly M.D. Orders. The industry accepted the concept of common access to markets without regulation. ${ }^{8}$

This is an example of co-operation between the regulatory authorities and the industry. The more urgent problem at present is not shortage of supply but limited market outside the province. The industry is threatened with over-production as is evidenced by prorationing schemes and persistent efforts for a greater share in the United States market.

(d) Measures relating to transportation charges and price of Oil and Gas

In practice, oil transportation charges are not regulated by the Government but are controlled by the forces of competition. However, the power of regulation is contained in section 101 of the Public Utilities Board Act. ${ }^{\times a}$ There is no problem as far as gas transportation charges are concerned since the pipe line company owns the gas it transmits. As regards oil transportation, traffic, tolls, or tariff are matters of negotiation between the producer and the refiner or between the producer and the pipe line company. Actually, integration in the industry and the common carrier nature of oil pipe lines makes regulations in all phases of transportation of oil almost unnecessary. The government does not regulate the price of crude oil; it is based on posted field prices. The posted price is not controlled by any one company and is truly competitive. Every producer has access to pipe line facilities. In the case of gas, the Gas Utilities Act ${ }^{\times b}$ [S.A. 1960, c. 37] 1960 contains provisions 
for the Public Utilities Board to regulate the undertaking of public utility companies, the price of gas at the well-head, and consumer price of gas at other stages as well as before its delivery to the ultimate consumer. It has been remarked that the price of gas is regulated to a far greater degree in Alberta than in any of the other Provinces and that the Gas Utilities Act "contemplates regulation of the price [of gas] at virtually any and every stage "from the reservoir to the burner tip'."

The Public Utility Board does not specifically fix rates. However, the approval of the Board is necessary before an increase beyond a fixed maximum rate is implemented.

\section{(e) Measures affecting monopoly and competition}

In Alberta, Pipe lines are owned and operated by three classes of companies: -

(1) The pipe line company which constructs and operates the main lines and their attendant gathering lines;

(2) Pipe line companies which are subsidiaries of oil companies and which construct and operate pipe lines to carry oil and gas to refineries; and

(3) The producing companies themselves which construct and operate flow lines, gathering lines and service. ${ }^{10}$

Thus most pipe lines are owned and operated by integrated oil companies.

The producing company integrates forward into the transportation phase as in (3) above or the refiner integrates backwards into transportation phase as in (2) above. The oil industry reveals characteristics of monopoly through its integration process. Integration in the industry is said to be primarily due to the general intensity of competition.

Our final and perhaps most important conclusion is that the formation and alteration of integration patterns is a manifestation of the working of competition in the oil industry.11

But there is no doubt that vertical integration, which started as a means of capitalising on the opportunities of a particular business situation in a competitive enterprise, ultimately manifests itself as a monopoly if it is not regulated. The only provisions in the Pipe Line Act that concerns the formation of monopolies are section $19(5)$ and 19(6). The effect, if any, of the section, is indirect. The consent of the Minister must be obtained for the sale, lease, or operation of a pipe line by a person other than the licensee. His consent is also required before an agreement for amalgamation can be entered into. It is doubtful if the section is aimed at preventing a situation in which pipe line operation is controlled by a handful of giant companies.

In pipe line operation, other carriers do not compete in the transportation of gas but oil pipe lines take traffic that might be handled by other carriers. Transportation cost by pipe line is lower than by trucks and railroads and the latter offer no serious competition to oil pipe lines.

9 (1964), 3 Alta. L. Rev., at 381.

10 Submission to the Royal Commission on Energy: Department of Mines and Minerals (1958), at 45 .

11 MeLean and Haigh: The Growth of Interorated Oil Companies (1954), at 674. 
The real problem that arises is competition, not in transportation, but in the oil industry. The integrated companies have many advantages over independent producers and independent refiners. The argument usually advanced runs thus: The use of profits realized by one subsidiary to offset the losses incurred by another is an abuse inherent in integration. The profit position of the integrated company remains the same if it charges itself a high rate for transporting its oil to its own refinery. But if it charges an independent producer at the same rate, it further augments its profit. High rates may induce the independent producer to sell to the integrated company and will eventually make it unprofitable for him to compete in the business of production. The independent refiner is similarly affected by the maneuvres of integrated companies. Although similar situations have arisen in the United States and may not be ruled out altogether in Alberta, it does not appear that abuses of monopoly and integration are any serious problem in the transportation phase of the oil industry. This is partly due to the fact that most producers are stockholders in pipe line companies, and in any case, each producer has access to an oil pipe line.

Limited protection is provided in sections 43 and 43 (a) of the Oil and Gas Conservation Act which prohibit discrimination in favour of one producer as against another, and one pool against another, and one's own production against another. These sections apply to a transporter that has been declared a common purchaser or common carrier. Either party can apply to the Conservation Board if the producer is of the opinion that the common purchaser has discriminated against him countrary to section 43 (a). Furthermore, section $42(2)$ provides as follows:

No proprietor of a pipe line who is a common carrier shall directly or indirectly make or cause to be made or suffer or allow to be made any discrimination of any kind as between any of the persons for whom any oil or gas is gathered, transported, handled or delivered by means of a pipe line.

Subsection (3) prohibits discrimination by the common carrier in respect of his own oil or gas or that in which he is directly or indirectly interested in whole or in part. The provision, like the ones for a common carrier and common purchaser, are hardly ever used but are there as a "threat" to induce the companies to maintain fair competition. It would appear that too much is left to the forces of competition especially as experience in the United States oil industry has shown, that the forces of competition do not always regulate themselves in the interest of consumers or of investors. As an instance in Alberta, fierce competition is raging between pipe lines carrying oil from the Peace River fields. Mitsue Pipe Line Limited constructed a line of $\mathbf{1 0 0}$ miles from Redwater to Peace River. Before another company, the Peace River Pipe Line Company, was granted a permit to extend its line to Peace River, the Mitsue Pipeline's rate was 25 cents per barrel. When the Peace River Pipeline commenced transportation, the Mitsue Pipeline Company reduced its rate to 18 cents per barrel. The Peace River Pipeline was forced to reduce its rate from nearly one dollar to 25 cents per barrel on the Rainbow Pipeline. Rates were also reduced on the Peace River Pipeline to meet the competition even though it had to transport the oil over a much longer route to the same terminal. The position is likely to worsen when the Rainbow fields increase production. This situation, caused by dup- 
lication of lines, gives rise to unnecessary competition for oil which in turn results in the reduction of rates. Rather than protect the investor's interests, the present policy endangers them. No pipe line company will continue to operate if the rates become uneconomic. The rates of the companies under discussion have been falling consistently.

In some phases of pipe line operations, the Government has encouraged monopoly. Thus,

since 1954, the Alberta Gas Trunk Line Company has been given an almost exclusive status as the builder of the gas grid system in Alberta and delivery to the Alberta terminals of extra provincial pipe lines are made only through the facilities of the company. ${ }^{12}$

The distribution of gas to the ultimate consumer is treated as a public utility and because of the essential nature of the services offered by distributing gas pipe line companies, their monopoly status is justified in public interest. They play the important role of setting an example to others as to the service and the price of their commodity. In spite of the favoured status of public utility gas companies, there is competition in the purchase of gas among the few purchasers. It is in the use of the facilities of the processing plant that unfair competition and discrimination are likely to occur. To guard against this, the Public Utilities Commissioners are empowered to decide the rate of return on investment that the company who owns the plant is to have. The Board has to do with the rating but not to determine the nature of the contract, and its decision is taken after public hearing.

\section{EFFECTIVENESS OF REGULATIONS}

The current system of granting pipe line permits is sometimes criticised on the ground that it is capable of giving rise to duplication of lines and facilities, which in turn results in economic waste. Inevitably, the increased cost is bound to be reflected in consumer price. In other words, it is contended that the Provincial Government should take a positive step to regulate the location of pipe lines and to reject an application if it considers that a proposed line is an unnecessary duplication of pipe lines. The real question is whether or not the forces of competition exercise such control as would hinder the duplication of lines and so avoid waste resulting from destructive competition. Mention has been made that section 7 of the Pipe Line Act does not make it obligatory on the part of the Minister to refer an application to the Conservation Board or to the Gas Utility Board; and under section 8, the Minister need not accept the advice of the Board. The writer is informed that many applications are approved without reference to any of the Boards. The point sought to be made is that without reference to the Board, there is little or no opportunity for anyone to raise an objection on the ground of duplication.

The attitude of the Department of Mines and Minerals is, basically that if any company is prepared to invest millions and millions of dollars in the construction and operation of a pipe line in an area that is adequately served with pipe line facilities, let the company go ahead! At the time of writing, three permits have been given for the construction of three

12 (1964), 3 Alta. L. Rev., at 370. 
pipe lines to serve the same area where one would be sufficient. In such a case, as soon as one company proceeds with construction, the Department writes to the other two to return their permits for cancellation. It seems that a permittee who is not in breach of any terms or conditions of the permit can refuse to return the permit for cancellation and may commence construction. Under the Act, the only course open to the Department (and this is what is followed in practice) is set out in section $9(2)$, that is, to

... prescribe a date by which construction of the line is to be commenced or completed.

If the permittee fails to commence or complete at the stipulated times, the Minister may cancel the permit. It is clear that this measure cannot, in all cases, stop duplication of lines, and, in any case, this procedure is a clumsy method of doing so. However, the writer is informed that no permittee has so far refused to return his permit for cancellation when ordered to do so. Even then, duplication of pipe lines has already set in.

In the final analysis, the main regulatory factor, which does not always work, is competition, with the Government adopting the attitude of actual control with minimum legislation. Admittedly, because of the heavy investment and hazardous economic nature of pipe line ventures, only large companies have sufficient capital to embark on the venture on their own. Furthermore, few companies have sufficient market demand to utilize the full capacity of a pipe line. The economics of business would normally discourage duplication but where it does not, regulation becomes inevitable.

Sometimes official control of pipe line business is indirect and yet effective. The common purchaser provisions in section 42 to 43 (a) of the Oil and Gas Conservation Act, 1957, are aimed at protecting the small operator, discouraging discrimination by large operators and regulating competition. Although no declarations under the sections have been made for a long time, knowledge by the large operator of the powers of the Minister in this regard acts as a "deterrent". Similarly, section 101 of the Public Utilities Board Act, 1960, gives the Board the power to regulate oil transportation charges, but the Board has not acted under this section. The power is in essence held over the heads of the companies to compel compliance with regulations. What operates in practice is a high price of oil at well-head (because it gives the companies a tax advantage) and low pipe line transportation charges. There is a limit, however, below which transportation charges cease to be economic.

Another way of looking at the effectiveness of the regulations and controls is to consider the results achieved. From March 31st, 1964 to March 31st, 1965, ten oil and thirty-five gas pipe line licences were granted and a total of 1,344 miles of pipe lines were constructed in Alberta, a decrease of 800 miles from 1963.13 The total mileage of pipe lines in the Province as at March 31st, 1965, is 15,076. ${ }^{14}$ Judging from the Annual Report of the Mines and Minerals Department for the fiscal year 1964/65, there was an overall progress in the industry. Reserves of crude oil

13 Sixteenth Annual Report of the Department of Mines and Minerals of the Province of Alberta. 1964/65 at 45.

14 Ibid, at 45 . 
and natural gas showed marked gains. Production was a record of 176 , 183,758 barrels. Pipe line sundry revenue for the same period was $\$ 10,542.90,{ }^{15}$ a drop from the figure of the previous year. The total revenue from April, 1949 to March, 1965, was $\$ 59,982.65 .^{16}$ These results are undoubtedly impressive.

It is necessary to point out that regulation does not always prove to be really adequate as a substitute for competition in fulfilling its function of preventing monopoly prices and profits, checking discrimination, reducing costs, and promoting evidence of public utility services. The difficulty lies in knowing where to regulate and to what extent. Writing on the function of oil pipe lines, D. E. Lewis commented: ${ }^{17}$

Because of competition and common carrier concept, detailed control and regulation are not required in all phases of oil pipe line operations. Generally, regulation may be limited to such matters as injury to persons and property, expropriation and franchise considerations to avoid duplication of trunk line operation.

Subject to regulations or measure of control to prevent duplication of pipe line and so increase the general level of competition, it is considered that the present control and regulations are effective and in the public interest where the economic climate is that of free economy. No one can afford to lose sight of the fact that the greater the regulation, the less attractive it is to investors who may consequently be compelled to reduce investment. The present system has provided the dual benefit of adequate transportation and increased competition.

\section{ALTERNATIVE FORMS OF CONTROL}

Maintenance of competition, the regulation of private enterprise and public ownership, and operation of industry are methods employed by governments to ensure that activities of business are so conducted as to serve the general interest. Public ownership of pipe lines has not been tried in Alberta. This is probably due to the emphasis on free and private enterprise as the basis of her economic policy and the present economic climate is against public ownership in general. But where competition has failed, private enterprise has given way to public enterprise.

Apart from outright public ownership and operation, state participation is a means of ensuring the control of business. If local capital is not available or is insufficient in an enterprise requiring substantial capital, as in the pipe line business, state participation is not only justified but imperative. At present, however, there is probably no justification for public ownership of pipe lines in Alberta. Can the same statement be made of state participation? From the point of view of material benefit to the Province from pipe line undertakings, an advocate of state participation or joint enterprise is not on a strong wicket. As mentioned earlier, in the 1964/65 fiscal year, the pipe line sundry revenue was $\$ 10,542.90$.

It was stated at the beginning of this paper that a policy on pipe lines must be related to the wider context of the policy on oil industry and the national economic policy. The present policy has, no doubt, led to

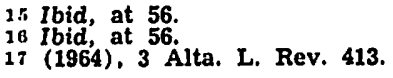


material progress; it has led to domination by foreign capital of oil business in Alberta, it has contributed to questions being asked such as: "Does Canada Have an Identity?"; "Canadian Foreign Policy-Made in U.S.A.?"; "Who owns Canada?"; "1986-Canada the 51th State?".

These questions, (contained in a hand-bill entitled "Teach-in Canada: Sovereign or Satellite", dated February 9th, 1966) were discussed by a panel of experts during Varsity Guest Week-end at The University of Alberta, Edmonton, Alberta. It is suggested that joint venture, not nationalisation, is one of the answers. Nations that receive foreign investment adopt such a measure to avoid economic domination in future.

In fairness to the present policy, the critics of the present apparent laissez-faire attitude are to be reminded that in 1937, the Alberta Government made efforts to attract capital from Montreal and Quebec; in 1938 an economic mission was sent to Britain for the purpose of attracting capital for the exploitation of natural resources in Alberta. No capital was forthcoming from Montreal, Quebec or London. As a result, the Government invited investment from any part of the world. Then American capital poured in; later. on capital from Britain and elsewhere followed and now the figure stands roughly at $80 \%$ foreign capital in Alberta's oil and gas industry. ${ }^{18}$ Naturally, the Government is unwilling to take steps to oust foreign capital that has contributed so immensely to the sound economy of the Province. However, there can be state participation (e.g. share holding) without depriving foreign investors of their acquired rights. At the present however, the Government sees no economic advantage in state participation in Alberta.

\section{CONCLUSION}

The efficiency of the present system cannot be fully explained in terms of regulations and public policy alone. The ownership of $90 \%$ of the oil and gas rights in Alberta by the Government and the strong powers under the Acts, which can be employed if need be, put the Government in a strong position vis-a-vis the companies. In spite of that, the conduct of the Department of Mines and Minerals in dealing with the oil and gas companies is sincere and without discrimination. This inspires the confidence in the companies that the government is not arbitrary, capricious, dishonest or uncertain. It is not difficult to find an identity of interest between the Government and the companies.

Perhaps this paper attaches too much importance to public interest. Actually, in carrying out the pipe line policy, the Department does not attach much meaning to any particular public interest. A more practical approach is adopted. Such a pragmatic approach probably explains the cooperative attitude between the industry as a whole and the Department and also the remarkable success in the regulation of pipe lines by the Government. The Acts and Regulations, while reflecting the basic policy of the Government, constitute no more than a framework on which the successful system operates. The administrative practices and orders of regulatory bodies, in conformity with the broad intent of the Acts and regulations, are frequently in accord with the attitude of the industry. 